\title{
Desistência da adoção de crianças e de adolescentes durante o estágio de convivência: reflexões sobre uma possível responsabilização civil
}

\author{
Withdrawal of adoption of children and adolescents during the course of experience: \\ reflections on possible civil liability
}

\author{
Marcelo de Mello Vieira* \\ Marina Carneiro Matos Sillmann**
}

\section{REFERÊNCIA}

SILLMANN, Marina; VIEIRA, Marcelo. Desistência da adoção de crianças e de adolescentes durante o estágio de convivência: reflexões sobre uma possível responsabilização civil. Revista da Faculdade de Direito da UFRGS, Porto Alegre, n. 46, p. 93-125, ago. 2021. DOI: https://doi.org/10.22456/0104-6594.107714.

\begin{abstract}
RESUMO
A adoção consiste em instituto voltado a atender aos interesses da criança e do adolescente adotando, sendo estabelecido pelo Estatuto da Criança e do Adolescente o tramite normativo. Destaca-se o procedimento de habilitação e o estágio de convivência. Ocorre que, mesmo tomando todos os cuidados, ainda se observa na prática a situação de desistência da adoção durante o período de convivência por um ato de vontade dos adotantes. Sendo assim, o presente trabalho tem por objetivo analisar a possibilidade de aplicação da responsabilidade civil nos casos de desistência da adoção. Para concretizar o presente estudo, utilizar-se-á a pesquisa teórica e a análise de julgados. Por sua vez, o método a ser empregado na pesquisa será por meio do estudo monográfico e legislativo de obras que trataram a temática proposta.
\end{abstract}

\section{PALAVRAS-CHAVE}

Adoção. Responsabilidade civil. Desistência da adoção. Estágio de convivência.

\begin{abstract}
Adoption consists of an institute aimed at serving the interests of the child and adolescent, with the normative procedure being established by the Child and Adolescent Statute. Special attention to the qualification procedure and the coexistence stage must be given. It happens that, even taking all precautions, the situation of return of the child only based on the will of the adults during the period of coexistence is still observed in practice. Therefore, the present study aims to analyze the possibility of applying civil liability in cases of withdrawal from adoption. To carry out the present study, theoretical research and the analysis of jurisprudence will be used performed. The applied method for the research will be through the monographic and legislative study of works that dealt with the proposed theme.
\end{abstract}

\section{KEYWORDS}

Adoption. Civil liability. Withdrawal from adoption. Coexistence stage.

\section{SUMÁRIO}

1. Introdução. 2. Breves considerações sobre a adoção. 3. reflexões sobre a habilitação para a adoção. 4. Período de aproximação entre adotantes e adotado e estágio de convivência. 5. Desistência da adoção: repercussões para o adotando. 6. Reflexões sobre uma possível responsabilidade civil dos desistentes da adoção. 6.1. Impossibilidade de responsabilidade civil: direito dos adotantes à desistência da adoção. 6.2. Impossibilidade de responsabilidade civil: desistência sempre como inadaptação mútua. 6.3. Possibilidade de responsabilidade civil: a análise do caso concreto. 6.3.1. Motivo. 6.3.2. Modo. 6.3.3. Tempo. 7. Conclusão. Referências. Dados da publicação. 


\section{INTRODUÇÃO}

A adoção é uma tradicional instituição do Direito Civil, em especial do Direito das Famílias, que sofreu grandes alterações durante o desenvolvimento do Direito nacional, das quais a mais profunda ocorreu com o advento do Estatuto da Criança e do Adolescente. Em razão disso, a adoção deixou de ser analisada pelo viés privatista do Código Civil, que buscava satisfazer os desejos das famílias, para focar nos interesses da criança e do adolescente. Por esse motivo, essa instituição deve ser necessariamente relida por meio dos princípios constitucionais e pelos princípios do direito infantojuvenil.

Apesar dessa alteração de foco se refletir em robustas mudanças legislativas, que até hoje estão sendo aprimoradas, nas quais enfatizou-se a necessidade da preparação dos interessados para adoção e um cuidado especial durante o período de convivência, essa modificação ainda não foi totalmente compreendida pela sociedade brasileira. Embora, inegavelmente, tenha aumentado o número de crianças e adolescentes adotados, ${ }^{1}$ tem também chamado atenção o número de casos de desistências de adoção e devoluções de adotados, o que, em tese, representaria uma forma de violação dos direitos dessas pessoas em desenvolvimento e que gozam de proteção jurídica especial e prioritária segundo o texto constitucional.

A desistência de adoção é aquela que ocorre durante o estágio de convivência, quando já deferida a guarda provisória ou termo equivalente (no caso da adoção internacional), e a devolução é aquela que ocorre após o deferimento do pleito, o que corresponde ao abandono de filho. O presente estudo visa analisar apenas a desistência da adoção e a possibilidade da responsabilidade civil nos casos em que a adoção não se concretiza por um ato de vontade dos adotantes.

Para tanto, será feita uma breve análise sobre o que representa a adoção para o Direito da Criança e do Adolescente, em especial, acerca da habilitação para adoção e do período de aproximação entre adotantes e adotando. Em um segundo momento, será analisada a hipótese de desistência da adoção por ato do adotante, que desiste da guarda para fins de adoção, e suas repercussões para o adotando. Serão observadas três correntes encontradas nas decisões de tribunais estaduais que tratam da temática: existência de um direito dos adotantes à desistência da adoção; impossibilidade de responsabilização por se tratar de inadaptação mútua e

\footnotetext{
${ }^{1}$ Os números referentes à desistência ou à devolução de adoção não são divulgados pelo CNJ nem pelos tribunais. Segundo dados obtidos junto a onze estados da federação, no período entre 2012 e 2017, houve cento e setenta e duas desistências de crianças e/ou de adolescentes nesses estados (LAVOR, 2017).
} 
possibilidade de responsabilização civil a partir da análise do caso concreto, observando os fatores motivo, modo e tempo da desistência.

\section{BREVES CONSIDERAÇÕES SOBRE ADOÇÃO}

A Constituição da República Federativa do Brasil de 1988 (CRFB/1988) trouxe profundas modificações no tratamento dado à população infantojuvenil. Dentre essas alterações, a adoção foi retirada do Código Civil, legislação historicamente marcada pela defesa dos interesses individuais de particulares, e foi inserida no direito infantojuvenil, mais especificamente no direito de crianças e de adolescentes à convivência familiar. Com isso, toda uma sistemática e a principiologia própria, constantes no texto constitucional e na Convenção dos Direitos da Criança, voltadas exclusivamente para o atendimento dos interesses infantojuvenis, passaram a ser aplicadas à adoção, fazendo com que esta deixasse de ser um instrumento que visava atender aos interesses familiares, passando a voltar o seu foco apenas para a criança.

Esse direito à convivência familiar foi traduzido no Estatuto da Criança e do Adolescente (Lei n. 8.069/1990) como o "direito da criança e do adolescente ser criado e educado no seio de sua família e, excepcionalmente, em família substituta, assegurada a convivência familiar e comunitária, em ambiente que garanta seu desenvolvimento integral" (art. 19 do Estatuto da Criança e do Adolescente). ${ }^{2}$ Essa previsão, aliada aos outros dispositivos presentes na mesma lei, representou "um rompimento com a tradição brasileira de abrigamento de crianças nascidas em famílias consideradas, pelo Estado, desestruturadas, primando pela manutenção do infante no seio familiar sempre que possível." (VIEIRA, SILLMANN, 2020, p. $67)$.

Assim, dentro desse direito, o papel reservado para a adoção é excepcional e subsidiário, e não de protagonismo, já que este é da família natural, comunidade formada pelos pais e seus descendentes (art. 25 do Estatuto da Criança e do Adolescente). O Direito nacional aposta da capacidade desta família de se organizar para desempenhar seu papel primordial de proteção da prole. É por isso que, havendo qualquer sinal de vulnerabilidade, medidas devem ser aplicadas

\footnotetext{
${ }^{2}$ Todavia, para compreender sua real extensão, a convivência familiar deve ser tratada de forma mais ampla e entendida como um direito que visa proteger e promover a garantia da criança e do adolescente de formar e manter laços saudáveis com seus familiares e até com outras pessoas que lhes tragam benefícios, laços estes que representem a sua efetiva integração à vida familiar em um ambiente adequado ao desenvolvimento de sua autonomia e personalidade. Essa integração deve também incluir a real participação nas rotinas, nos rituais e nas decisões que envolvem sua família (VIEIRA, 2019, p. 107).
} 
à criança e ao adolescente e aos pais ou representantes legais para que elas sejam superadas (art. 101 e 129 da Lei n. 8.069/1990).

Somente caso comprovada a inaptidão, ainda que provisória, ${ }^{3}$ dessa família natural para desempenhar o mencionado papel é que deve se buscar a família ampliada, aquela composta de parentes próximos com os quais existam liames de afinidade, afetividade e convivência (art. 25 parágrafo único da Lei n. 8.069/1990). Nota-se, então, que o direito à convivência familiar é um direito que busca garantir a manutenção dos vínculos que a criança já possui e também reafirmar a responsabilidade daqueles que possuem laços de parentesco, efetivando a responsabilidade familiar (não só dos pais) no zelo dos direitos infantojuvenis como determina o art. 227 da CRFB/1988).

Somente não havendo membros da família natural ou da família ampliada capazes de exercer o múnus protetivo é que a família substituta se torna uma opção legalmente correta para assegurar esse direito à convivência familiar. Dessa forma, só nessa situação é que a adoção se torna uma opção legalmente correta (e não a sempre mais correta) para a população infantojuvenil.

Essa mudança legislativa ainda não foi totalmente compreendida pela sociedade brasileira (inclusive pela comunidade jurídica, em especial, por parte dos autores e profissionais que lidam com o direito de família), que insiste em manter viva a cultura menorista, que culpabiliza a família natural e defende o rompimento desses vínculos, apontando para a adoção como sempre a melhor resposta. ${ }^{4}$

A adoção não é caridade nem assistencialismo, é uma instituição jurídica com o ideal de proteção de crianças e adolescentes. Reitere-se que sua aplicação é excepcional, como determina expressamente o art. $39 \S 1^{\circ}$ do Estatuto da Criança e do Adolescente e implicitamente

\footnotetext{
${ }^{3}$ Verificada a impossibilidade temporária para a criança ficar em sua família natural, ela deve ser encaminhada para a família ampliada como já dito ou para acolhimento familiar ou institucional e as medidas previstas no art. 129 da Lei n. 8.069/1990 devem ser aplicadas aos pais ou responsáveis para que essa situação de vulnerabilidade seja superada e o filho possa retornar ao seu de sua família.

4 A manutenção dessa cultura menorista é perceptível em diversos julgados, em projetos de lei e até em renomados autores de Direito de Família. Carlos Nakamura (2019, p. 181) compartilha as reflexões de Oliveira, nas quais o autor aponta que alguns discursos políticos que embasam projetos de lei relacionados à adoção se posicionam pelo rompimento de vínculos com a família natural sob o pretexto garantir "o melhor interesse da criança", o que tem grandes repercussões em famílias mais vulneráveis. Esse alerta se mostra verdadeiro quando se analisa as modificações realizadas pela Lei n. 13.509/2017, que fragilizaram a manutenção na família natural e previu ações concretas com essa finalidade, sob o argumento de que há muitas crianças em acolhimento institucional e muitas famílias querendo adotar. Medidas como essa visam atender mais o perfil procurado pelos pretensos adotantes do que o perfil de crianças e adolescentes disponíveis para adoção, ou seja, atender aos desejos dos adultos e não aos interesses infantojuvenis. Com isso, se insiste em não atacar o problema e "persiste o desencontro entre o perfil real de crianças/adolescentes disponíveis à adoção e o perfil desejado pelos pretendentes habilitados." (NAKAMURA, 2019, p. 182).
} 
o art. $9^{\circ}$ da Convenção Internacional dos Direitos da Criança de 1989 (CIDC/1989). É justamente para preservar essa excepcionalidade que são previstas várias garantias que são necessárias em razão de a adoção ser o único mecanismo jurídico lícito e voluntário capaz de criar um novo estado de filiação. ${ }^{5}$

O sistema jurídico idealizado para a adoção no Brasil foi aperfeiçoado ao longo dos anos e, atualmente, é baseado no Sistema Nacional de Adoção e Acolhimento (SNA), o qual, na verdade, é a integração de dois cadastros distintos, um que congrega aqueles que estão disponíveis para adoção ${ }^{6}$ e outro dedicado às pessoas aptas em adotar. Enquanto o primeiro é composto de crianças e adolescentes que, em regra, não estão mais sujeitas ao poder familiar nem sobre a proteção da família extensa, o segundo é integrado por aqueles que foram legalmente considerados capazes para exercer a paternidade/maternidade via adoção. Essa aptidão ou capacidade para adotar é verificada em procedimento administrativo, presidido pelo juiz da Infância e da Juventude de cada comarca, que, além de habilitar o interessado a integrar o cadastro nacional de adotantes, funciona como uma parte importante da preparação desses interesses para o exercício da paternidade/maternidade.

\section{REFLEXÕES SOBRE A HABILITAÇÃO PARA ADOÇÃO}

O procedimento de habilitação para adoção, previsto nos arts. 197-A a 197-F do Estatuto da Criança e do Adolescente, inicia-se com o registro do pedido de habilitação no site do CNJ, mas se efetiva com um pedido formal feito pelos interessados que deve ser acompanhado do registro feito no $\mathrm{CNJ}$, da documentação pessoal, do atestado de sanidade física e mental e das certidões de antecedentes criminais e de negativa de distribuição cível. Ou seja, já de início é necessário que os pretensos adotantes comprovem, ao menos formalmente, terem boa saúde e não terem contra si ações cíveis ou criminais, o que representaria, em tese, idoneidade moral. Os postulantes também apresentam o perfil da criança ou do adolescente que desejam adotar, explicitando faixa etária, etnia, gênero e se aceitam grupos de irmãos e criança que possua

\footnotetext{
${ }^{5} \mathrm{O}$ reconhecimento voluntário de paternidade é também uma forma de modificação do estado de filiação, mas, em tese, não se trata de um novo estado, e sim de reconhecimento de filiação original. O mesmo entendimento deve ser utilizado nas hipóteses de reconhecimento judicial de paternidade socioafetiva, que, por meio de uma decisão, declara a paternidade, que é equiparada para todos os efeitos à paternidade biológica.

${ }^{6} \mathrm{Na}$ verdade, esse cadastro de crianças é mais amplo, porque ele contém informações sobre de as crianças e adolescentes em medida de acolhimento no país.
} 
alguma deficiência. ${ }^{7}$ É muito importante ter em mente que, caso deferida a habilitação, é justamente esse perfil que determina o tempo de espera dos interessados, isto é, quanto menos restrições existirem no perfil desejado (ou quanto mais inclusivo for esse perfil), menor será o período que esses adotantes esperarão por uma criança.

Após a participação do Ministério Público, que, além de examinar a documentação apresentada, pode formular quesitos para serem respondidos no estudo técnico a ser realizado, requerer oitiva de testemunhas, de complementação da documentação e até a realização de diligências (art. 197-B da Lei n. 8.069/1990), o feito é encaminhado para a equipe técnica do Juízo da Infância e da Juventude para a elaboração de um estudo psicossocial dos postulantes. Esse estudo é importante porque, de acordo com o art. 197-C da Lei. n. 8.069/1990, nele são colhidos "subsídios que permitam aferir a capacidade e o preparo dos postulantes para o exercício de uma paternidade ou maternidade responsável, à luz dos requisitos e princípios desta Lei." Esse é o momento que psicólogos e assistentes sociais judiciais têm contato com os interessados e poderão traçar o perfil psicossocial destes, conhecer as motivações para adotar e expectativas, além de compreender o que os postulantes entendem por adoção e paternidade/maternidade e desmistificar alguns pontos sobre a adoção.

A análise das razões para adotar é especialmente relevante, já que toda adoção deve se fundamentar em motivos legítimos (art. 43 do Estatuto da Criança e do Adolescente). Altruísmo, religiosidade, busca pela salvação de casamento, dentre outros ${ }^{8}$ são alguns exemplos de motivação que não podem ser considerados legítimos. Riede e Satori pontuam que a identificação de "possíveis causas de perigo para a inclusão da criança na condição de filho deve ser requisito essencial e obrigatório ao momento que antecede a adoção, ou seja, no pedido de habilitação dos candidatos.” (RIEDE, SATORI, 2013, p. 145). Refletir sobre a motivação é algo que deve ser feito antes da entrega da criança ao interessado para que se evite qualquer

\footnotetext{
${ }^{7}$ Trata-se de um procedimento que dispensa a participação de advogado e que admite o uso de formulários padronizados. O Tribunal de Justiça de Minas Gerais, por exemplo, disponibiliza em seu sítio eletrônico um modelo de petição editável, que pode ser encontrado no link: https://www.tjmg.jus.br/portaltjmg/servicos/adocao.htm\#.Xvn0SihKjIU.

${ }^{8}$ São muitos os outros possíveis exemplos de motivação ilegítima. Gina Levinzon aponta que " $[\mathrm{H}]$ há uma ampla gama de motivos que levam um casal a adotar uma criança: questões de infertilidade; pais que afirmam que 'sempre pensaram em adotar'; a morte de um filho biológico; o contato com uma criança abandonada que suscita o desejo de cuidar dela; o desejo de ter filhos quando já não é mais possível biologicamente; o parentesco com pais biológicos que não podem cuidar da criança; pessoas que não possuem um parceiro, mas querem exercer a maternidade ou a paternidade; o medo de uma gravidez; o argumento de que 'há muitas crianças necessitadas' e é melhor adotá-las do que pôr mais crianças no mundo." (LEVINZON, 2006, p. 25).
} 
espécie de risco ao adotando, inclusive o risco de desistência ou devolução. (BERTONCINI, CAMPIDELLI, 2018, p. 85).

O motivo legítimo, então, seria aquele que se liga ao aspecto protetivo da adoção. Nesse contexto, os postulantes devem compreender que a criança não é meio de atender seus desejos e expectativas, mas sim, que eles são parte de um projeto dedicado à formação pessoal e cidadã do adotando (RIEDE, SATORI, 2013, p. 145) que se dará pelo acolhimento daquela criança (de suas características pessoais, de sua história, etc.) e pelo exercício responsável da paternidade/maternidade.

Nesse momento também é primordial que sejam trabalhadas com esses interessados questões ligadas às expectativas por eles criadas quanto à adoção. Expectativas e idealizações quanto aos filhos são comuns na paternidade/maternidade (tanto biológica como na adotiva). Entretanto, elas devem ser trabalhadas para que não se tornem fonte de decepções e de frustrações que podem inviabilizar a construção da relação familial (RIEDE, SATORI, 2013, p. 145). Sobre esse delicado tema, Aline Kirch e Lívia Copatti ensinam que:

\footnotetext{
a fantasia do filho ideal existe no imaginário de todos os que pretendem ter ou tem filhos, independente (sic) de serem eles biológicos ou adotivos. Os pais idealizam que o filho terá determinada personalidade, valores, princípios, formas de agir e pensar advindos da maneira que pretendem criá-los. Entretanto cada um dos seres humanos é dotado de convicções, e experiências próprias que são baseadas não somente na criação dada ou planejada pelos pais, mas também em outros fatores internos e externos que formam a personalidade.

Assim, todas as pessoas são dotadas de qualidades e defeitos. Passam por situações problemáticas, conflituosas, de questionamentos, incertezas e convicções em suas vidas, principalmente na fase da adolescência.

Consequentemente, qualquer filho, biológico ou adotado, passa por problemas e tem relações de conflito com os pais e com o meio em que vivem. Algumas pessoas, porém, não adquirem esta percepção, sendo este um grave fator de risco que contribui para a devolução.

Estas pessoas possuem o desejo de adotar, ou imaginam que o possuem, muitas vezes advindo da situação de infertilidade ou por serem solteiras e sozinhas e pensam que o filho adotado deve gratidão pelo seu "gesto de bondade". Exigem da criança ou adolescente um comportamento perfeito, criando idealizações e altas expectativas, não admitindo os erros e defeitos do filho. (KIRCH, COPATTI, 2014, p. 24).
}

Além das expectativas quanto ao filho, Maria Luiza Ghirardi destaca que é também necessário combater o imaginário social da adoção, que, segundo ela, “é atravessado por ideias de que o amor modificará todas as anteriores vivências penosas da criança e as salvará do abandono original." (GHIRARDI, 2015, p. 98). Identificações instantâneas ou amores à primeira vista podem ocorrer, mas acreditar que isso deve acontecer ou que o amor por si só já basta é romantizar a adoção e criar expectativas que, na maioria das vezes, são inatingíveis, o 
que pode comprometer a relação de parentesco que se inicia. Por isso, é essencial que, durante o procedimento de habilitação, os técnicos da justiça infantojuvenil esclareçam sobre essas questões e provoquem reflexões sobre essas expectativas. É essencial que os adotantes compreendam que tanto "[O] o ato de gerar outra vida ou de assumi-la através do ato jurídico da adoção impõe aos pais o dever de cuidar em todas as suas dimensões, desde a manutenção da sobrevivência até a educação e formação moral." (SOUZA, 2013). Isto é, a despeito da origem do liame, a paternidade/maternidade adotiva gera os mesmos direitos e deveres e, praticamente, os mesmos desafios da paternidade biológica. Deve ficar claro que a construção da relação paterno-filial não é algo mágico ou natural, e sim fruto de um trabalho diário que envolverá aceitação, esforço, alegrias, tristezas, etc. ${ }^{9}$

Após a avaliação, passa-se para uma outra etapa do procedimento, a inscrição dos interessados em programa de preparação para adoção. Como advertem Carla Bertoncini e Laísa Campidelli (2018, p. 85-86), a preparação para receber uma criança para adoção é tão importante como o período de gestação biológica, uma vez que possibilita pensar no tipo de pais que os pretensos adotantes querem ser. Esse preparo deve envolver reflexões sobre o exercício da paternidade/maternidade e deve também trabalhar questões específicas referentes à adoção, especialmente aquelas que envolvem o direito da criança ao conhecimento de sua origem e como lidar com o preconceito contra os filhos não biológicos que ainda existe em nossa sociedade.

Esses programas devem ser oferecidos pela Justiça Infantojuvenil, contando, de preferência, com o apoio da equipe técnica do município que executa a política de garantia do direito à convivência familiar e dos grupos de apoio à adoção cadastrados no Juízo da Infância

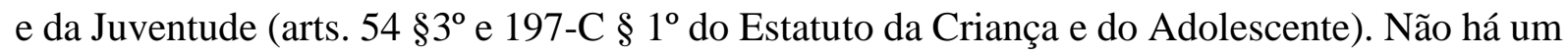
padrão legal que determina a forma como esses programas são desenhados, devendo cada tribunal estadual regulamentar o desenho de seus respectivos cursos. Cursos online, palestras, dinâmicas, todas são opções válidas para que seja realizada essa preparação dos postulantes nos mais diferentes aspectos que envolvem a adoção, devendo incluir ainda "preparação psicológica, orientação e estímulo à adoção inter-racial, de crianças ou de adolescentes com deficiência, com doenças crônicas ou com necessidades específicas de saúde, e de grupos de irmãos.” (art.

\footnotetext{
${ }^{9}$ Em alguns locais, a avaliação psicossocial é feita após a realização dos cursos. Embora isso ocorra mais por uma questão prática de tentar encaixar os postulantes nos cursos mais próximos e, com isso, agilizar a habilitação, a participação prévia nesses cursos poderia ser interessante para que os interessados pudessem ter mais conhecimento e, quem sabe, pudessem até chegar para a entrevista técnica com uma outra ideia de perfil de adotandos.
} 
197-C $\S 1^{\circ}$ da Lei n. 8.069/1990). Essa previsão constante na parte final do art. $197-C \S 1^{\circ}$ do Estatuto da Criança e do Adolescente busca ajudar os pretensos adotantes a refletir se querem ampliar o perfil inicialmente traçado de crianças que desejam receber. Nessa mesma linha, foi previsto como etapa obrigatória, sempre que possível e recomendável, o contato dos postulantes com crianças e adolescentes que se encontram em acolhimento (familiar ou institucional), contato esse realizado com orientação e sob supervisão dos técnicos responsáveis pela execução

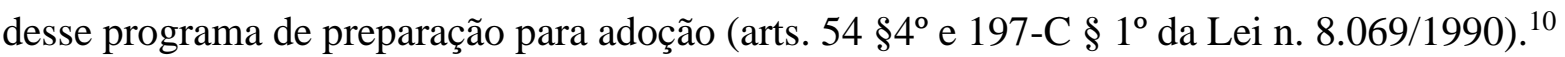

Todos os dados colhidos pela equipe técnica do Juízo referentes à capacidade dos postulantes em exercer a paternidade/maternidade, incluindo aspectos psicológicos, motivações e quaisquer outros fatores que possam influir no deferimento do pedido, devem ser incluídos nesse estudo que, juntamente com todo o procedimento, será encaminhado ao Ministério Público. Nessa nova fase, é averiguada a regularidade do procedimento e poderão ser requisitadas novas diligências ou até audiência de instrução e julgamento. Caso já tenha sido apresentado parecer ministerial pelo deferimento ou não do pedido de habilitação, o juiz profere a decisão (art. 197-D da Lei. n. 8.069/1990).

Somente após a análise e a decisão judicial de deferimento é que os postulantes são efetivamente inscritos no SNA, e a convocação deles para receber uma criança deverá, em regra, observar a ordem cronológica de inscrição para aquele perfil por eles desejado. Como já mencionado, quanto mais restrito for o perfil, maior será a espera. ${ }^{11}$

Apesar desse procedimento descrito parecer ser longo, ele deve demorar cento e vinte dias, só podendo tal prazo ser ampliado mediante decisão judicial (art. 197-E da Lei n. 8.069/1990). Essas etapas e exigências "não são mera burocracia estatal, mas sim cautelas necessárias para não se colocar uma criança ou um adolescente em risco, cautelas estas que não

\footnotetext{
${ }^{10}$ Andréa Mendes e Kelda Rocha criticam a obrigatoriedade desse contato. Segundo elas, "[O] o art. 50, $\S 4^{\circ}$ do ECA possui uma exigência particularmente tenebrosa que é a obrigatoriedade da visitação dos candidatos à adotantes aos possíveis adotados aptos para a adoção que encontram-se sob a guarda do Estado. Considerando que a visita é tão somente para que seja feita a habilitação, tal etapa do procedimento expõe a criança e o adolescente em demasia e gera esperanças que podem não vir a serem satisfeitas." (MENDES, ROCHA, 2018, p. 23). O posicionamento das autoras tem certa razão quando analisado somente pelo prisma de expectativas criadas pelas crianças e adolescentes nas entidades de acolhimento. Contudo, elas não analisam o potencial que tais visitas podem ter para que aquelas ou outras crianças e adolescentes sejam adotados ou para que seja ampliado o perfil de interesse dos postulantes para que outros sejam adotados. É sim uma questão que deve ser ponderada, porque envolve outros fatores, inclusive como os interessados lidariam com essas visitas, mas é até por isso que a lei coloca a expressão "sempre que possível e recomendável".

${ }^{11}$ Importante consignar que o art. 197-E $\$ 2^{\circ}$ do Estatuto da Criança e do Adolescente determina a necessidade de renovação da habilitação, no mínimo, a cada três anos por meio de avaliação pela equipe técnica judicial, ou seja, se o perfil escolhido pelos adotantes for muito específico, pode ser que o cadastro dele seja reavaliado pelos menos uma vez, já que, dependendo as exigências desses perfis, pode fazer com que o período de espera seja até mais que três anos.
} 
são observadas quando a adoção não segue tais procedimentos." (VIEIRA, SILLMANN, 2020, p. 75).

Como bem salienta Sabrina Cruz (2014, p. 19), apesar de todos esses cuidados, é praticamente impossível prever exatamente como será o comportamento dos habilitados quando eles efetivamente receberem a criança, já que existe uma esfera íntima que todo ser humano reserva para ele mesmo. Todavia, a mesma autora adverte que:

tal processo, na maioria das vezes, é eficaz e consegue filtrar os chamados perfis incompatíveis com a adoção, pessoas que acreditam ter as condições necessárias a suportar o ônus decorrente do poder familiar, mas que só se concentraram no lado positivo de se ter um filho. (CRUZ, 2014, p. 19).

Sempre que uma criança é inserida no cadastro de pessoas aptas a serem adotadas, é feita uma busca no cadastro de pessoas habilitadas para adotar que desejam um adotando com aquele perfil e, quando coincide a ordem dos postulantes com o perfil da criança, tem início a aproximação das duas partes. Esse período de aproximação é também acompanhado pelos técnicos judiciais e funciona também como um segundo filtro para aferir o comportamento dos postulantes quando começam a ter efetivo contato com a criança.

\section{PERÍODO DE APROXIMAÇÃO ENTRE ADOTANTES E ADOTANDO E ESTÁGIO DE CONVIVÊNCIA}

O processo de aproximação entre os postulantes e adotandos inicia-se, geralmente, quando uma criança com o perfil almejado está disponível e os adotantes são os próximos na ordem cronológica do cadastro. Os interessados são convidados a conhecer a criança e sua história, de forma a ficarem a par de eventuais peculiaridades referentes à origem do adotando. ${ }^{12}$ Não é incomum que recém-nascidos ou infantes em tenra idade já sejam entregues aos pretensos adotantes sob guarda já nesse primeiro contato, mas quanto mais velho for o adotando, mais

\footnotetext{
${ }^{12} \mathrm{O} \S 4^{\circ}$ do art. 197-E do Estatuto da Criança e do Adolescente preconiza que "[A] após 3 (três) recusas injustificadas, pelo habilitado, à adoção de crianças ou adolescentes indicados dentro do perfil escolhido, haverá reavaliação da habilitação concedida." Em uma análise mais literal, poderia concluir-se que o interessado teria "duas chances" de escolher um adotando que mais lhe agradasse por qualquer motivo, ainda que fosse um motivo completamente fútil, como cor dos olhos ou tipo de cabelo. Não é para permitir caprichos que tal previsão existe. Por mais que o habilitado se prepare, é impossível prever qual será o exato momento que ele será contatado para conhecer o adotando e isso pode ocorrer quando ele estiver em viagem ou em momento no qual por circunstâncias pessoais não pode receber a criança. Fazer o adotando esperar por dias ou até semanas é, em regra, prejudicial ao seu desenvolvimento. É para situações assim que esse dispositivo deve ser usado. No entanto, se sempre que é chamado, o habilitado não está disponível para receber o adotando, faz-se, de fato, necessário que sua habilitação seja, pelo menos, reavaliada.
} 
intervenções deverão ser realizadas com ele, visando prepará-lo para também receber os adotantes.

Embora o art. 197-C $\S 3^{\circ}$ da Lei n. 8.069/1990 afirme que essa preparação de crianças e de adolescentes que estão em acolhimento (tanto familiar como institucional) para inclusão em família adotiva seja recomendável, a ótica de proteção que permeia todo o direito infantojuvenil mostra que ela é necessária, uma vez que seu intuito é facilitar a possível construção da relação paterno/materno-filial. Géssica Carnaúba e Jhainieiry Ferret ensinam que:

de forma geral, a preparação das crianças consiste em intervenções que facilitem a elaboração do luto pela perda da família de origem, e no caso de terem passado pelo abrigo, elaboração do rompimento de vínculos construídos durante o tempo na instituição, para que depois disso, possam estabelecer uma nova relação familiar. (CARNAÚBA, FERRET, 2018, p. 124).

O rompimento de quaisquer vínculos, inclusive aqueles dos adotandos com seus cuidadores, seja na família acolhedora, seja na entidade de acolhimento, bem como a construção de novos laços com os interessados, devem ser feitos de forma gradual. Geralmente, inicia-se com a visitação e, posteriormente, permite-se que os adotantes passem, gradativamente, mais tempo com os adotandos, primeiro com passeios fora da entidade, depois com o convívio durante os fins de semana, até que se tenha confiança para iniciar o estágio de convivência, que efetivamente começa com o deferimento da guarda provisória.

É importante ter em mente que esse período de aproximação não se confunde com o estágio de convivência, já que essa aproximação é, normalmente, dispensada quando se trata de criança em tenra idade. Nos casos em que a criança está na maternidade, que há o interesse da sua entrega pela mãe que foi acompanhada pela equipe técnica do Juízo e não há parentes da família extensa que queriam cuidar do infante, não há o encaminhamento para uma instituição de acolhimento, sendo ela já acolhida por uma família substituta cadastrada, conforme já tratado. Já o estágio de convivência só pode ser dispensado quando a criança estiver sob guarda legal ou tutela dos adotantes por um longo tempo (art. $46, \S 1^{\circ}$ e $\S 2^{\circ}$ do Estatuto da Criança e do Adolescente). ${ }^{13}$

\footnotetext{
${ }^{13}$ Gagliano e Barretto (2020) defendem que esse período de aproximação é o estágio de convivência em sentido estrito, que termina com a concessão da guarda e que, nesse período, há um direito potestativo dos interessados em desistir da adoção. Esse entendimento possui alguns equívocos graves. O primeiro deles já foi dito, que é a impossibilidade de dispensa de estágio de convivência nos casos de recém-nascidos, embora não haja período de aproximação. O segundo equívoco é que o processo de adoção deve durar no máximo cento e vinte dias e o estágio de convivência até noventa dias. Se os prazos fossem rigorosamente seguidos, pelo entendimento dos autores, toda essa adoção duraria duzentos e dez dias, o que não condiz com o espírito de celeridade do Estatuto da Criança e
} 
Pode-se definir o estágio de convivência como "o período mínimo de avaliação da adaptação do adotando ao novo lar (família substituta), objetivando que o Poder Judiciário, com o apoio da equipe interprofissional (Psicólogos e Assistentes Sociais etc.), decida pelo deferimento ou não da adoção.” (COSTA, 2009, p. 166). Ele é, portanto, um período prévio ao deferimento da adoção, no qual adotantes e adotandos são acompanhados pela equipe interprofissional a serviço da Justiça infantojuvenil, que, ao final, elabora um relatório minucioso sobre a convivência nesse período, se possível em parceria com os técnicos que executam a política de convivência familiar, e manifestam-se sobre a conveniência da adoção (arts. 46, caput, $\S 3^{\circ}$-A e $\S 4^{\circ}$ do Estatuto da Criança e do Adolescente).

Como já abordado, esse relatório deve analisar a adaptabilidade, isto é, "apurar, depois de decorrido certo lapso de tempo, se o adotante e o adotando se adaptaram mutuamente. É, na verdade, um período de prova tendente a detectar se o relacionamento entre ambos vingou satisfatoriamente." (SILVA, 1995, p. 120). ${ }^{14}$ O lapso temporal do estágio de convivência é relativamente curto, até noventa dias para adotantes nacionais e de trinta a quarenta e cinco dias para adoções transnacionais, e ambos os prazos são prorrogáveis por igual período por decisão judicial fundamentada (art. 46, caput, $\S 2^{\circ}$-A e $\$ 3^{\circ}$ da Lei n. 8.069/1990) ${ }^{15}$. O que é analisado não é a existência de vínculos consolidados, mas sim como é a interação entre adotantes e adotando, se esses laços começam a ser formados para serem fortalecidos diariamente pela convivência e se os pretensos pais estão dispostos a receber aquela criança e/ou aquele adolescente real que está sob sua guarda, aquele que tem sua própria subjetividade e sua própria história. Como bem resume Maria Luiza Ghirardi, o objetivo desse período é "verificar a possibilidade de construção da relação afetiva entre adotantes e adotado.” (GHIRARDI, 2015, p. 29).

\footnotetext{
do Adolescente, o qual foi reforçado por leis que modificaram esse estatuto. Deve-se ter em mente que o estágio de convivência termina com um laudo feito pela equipe técnica (art. 46, $\S 3^{\circ}$-A da Lei n. 8.069/1990), o que não ocorre no período de adaptação, e que só pode ser realizado após um maior período de convivência, que ocorre após o deferimento da guarda. Por fim, ao afirmar o direito potestativo dos adultos, os autores dão destaque à proteção dos interesses dos adultos e não das crianças e dos adolescentes, indo de encontro ao que determina o Direito nacional. É a visão adultocêntrica prevalecendo sobre o direito infantojuvenil.

${ }^{14}$ No julgamento da Apelação Cível n. 1.702.14.059612-4/001, o Desembargador do Tribunal de Justiça de Minas Gerais (TJMG) Caetano Levi ressaltou a necessidade da avaliação da adaptação mútua entre adotantes e adotando, afirmando que " $[\mathrm{O}]$ o estágio de convivência pode ser definido como um período destinado a avaliar a adaptação do adotando à família substituta e acompanhar a adaptação desta família à adoção." (MINAS GERAIS, 2018, p. 12).

${ }^{15}$ A fixação do prazo máximo de noventa dias para o estágio de convivência nas adoções nacionais e a possibilidade de sua renovação somente por decisão judicial fundamentada foram algumas das poucas boas inovações trazidas pela Lei n. 13.509/2017. Até então não havia prazo determinado, o que fazia com que crianças e adolescentes ficassem por longos anos sob guarda provisória, sem que fosse ajuizada a ação de adoção.
} 
Géssica Carnaúba e Jhainieiry Ferret (2018, p. 128) asseveram que, além de analisar esse início de formação de vínculos, é nesse estágio de convivência que os técnicos responsáveis podem identificar dificuldades no relacionamento e realizar um acompanhamento mais apropriado para ajudar tanto os adotantes como os adotandos a trabalharem essas dificuldades da melhor maneira possível. Jane Riede e Giana Satori (2013, p. 152) advertem também que esse período é muito importante para que as partes rompam com expectativas irreais que possam ter umas com as outras.

Logo, o estágio de convivência é um importante momento que acaba funcionando como um segundo filtro (ou outra garantia) para o adotando, que, se acompanhado corretamente, não servirá somente para analisar a dinâmica, ainda frágil, entre adotantes e adotando, mas poderá também auxiliar na construção da relação futura, já que podem ser identificadas e trabalhadas questões que podem atrapalhar ou até inviabilizar a construção da relação entre pais e filhos. Dentro dessas questões, as expectativas falsas são uma das mais tormentosas, mas outras, como a inadequação do perfil - seja porque houve modificação desse perfil em razão de convencimento do postulante, seja porque ele usou subterfúgios, como afirmar que aceita grupo de irmãos, para diminuir o tempo na fila - podem ser reconhecidas e, se possível, trabalhadas. O estágio de convivência é especialmente importante nas adoções diretas irregulares, aquelas nas quais os adotantes não são previamente cadastrados, ou seja, não passam pela preparação do procedimento de habilitação. Nelas, o estágio de convivência é o único filtro que o Poder Público possui para avaliar a capacidade dos postulantes, a preparação deles para o exercício da paternidade/maternidade responsável, a motivação e a conveniência da adoção. ${ }^{16}$

Deve-se esclarecer que esse estágio é uma garantia para a criança e/ou para o adolescente e não para os adotantes. Sobre essa questão, a Desembargadora do TJMG Hilda Teixeira da Costa, de forma clara, definiu que:

[...] o estágio de convivência é em prol da criança, e visa à verificação da adaptação ou não do adotando ao novo lar, não se prestando este estágio para que os pretensos pais adotivos decidam se vão adotar ou não, haja vista que tal decisão deve anteceder o efetivo ajuizamento do processo de adoção, para o fim de evitar danos à criança ou adolescente que já não puderam ficar com seus pais por alguma razão. (MINAS GERAIS, 2014b, p. 15-16).

\footnotetext{
${ }^{16}$ Lembrando que, excepcionalmente, o estágio de convivência pode ser dispensado quando o adotando estiver sob guarda legal (guarda de fato, por si só, não desobriga) ou sob tutela do adotante (art. $46, \S 1^{\circ}$ e $\S 2^{\circ}$ do Estatuto da Criança e do Adolescente) por um lapso temporal longo o suficiente para a consolidação de um vínculo.
} 
Todos envolvidos devem ter consciência de que o estágio de convivência não é um período de teste sujeito a arrependimento, mas um compromisso jurídico assumido perante o Poder Judiciário, e obrigações de natureza jurídica e ética são assumidas com o adotando. ${ }^{17}$ Como já mencionado anteriormente, o estágio de convivência se inicia com o deferimento da guarda provisória da criança e/ou do adolescente aos adotandos e, com isso, esses adotandos passam a ter o dever de prestar assistência educacional, material e moral ao seu pupilo e o direito de oposição a terceiros, conforme prevê o art. 33 do Estatuto da Criança e do Adolescente. Como asseverou a Desembargadora do TJMG Vanessa Verdolim Andrade, o instituto da guarda "não é mera detenção de algo como parecem entender os apelantes, ele implica obrigações dos pretensos pais adotivos e tem ampla repercussão na vida das crianças e adolescentes, principalmente no campo emocional.” (MINAS GERAIS, 2014, p. 15).

O estágio de convivência deve se findar com a elaboração do relatório que irá subsidiar a decisão final sobre o deferimento da adoção, porém ele também pode acabar precocemente quando os adotantes desistem da adoção. Essa desistência pode ter repercussões sérias para a vida da criança e/ou do adolescente, justamente aquele que é mais vulnerável e quem o Direito Nacional se compromete a proteger com prioridade absoluta.

\section{DESISTÊNCIA DA ADOÇÃO: REPERCUSSÕES PARA O ADOTANDO}

Após o estágio de convivência, período no qual é examinada a adaptabilidade das partes e identificadas eventuais fragilidades a serem trabalhadas e, futuramente, superadas, é possível que se conclua que não houve a formação de vínculos mútuos entre adotantes e adotandos ou que não há possibilidade desses liames se formarem. Nesse caso, nada mais natural que a guarda seja revogada, que a criança retorne ao acolhimento e que os interessados desistam da adoção. A questão é mais complicada quando o adotando começa a formar os vínculos e os adotantes decidem que não desejam adotar.

A desistência é, portanto, uma decisão dos adotantes que renunciam à guarda para fins de adoção, ou seja, quando a adoção ainda não foi deferida. Ela não se confunde com a

\footnotetext{
${ }^{17}$ Em sentido semelhante, Lídia Levy, Patrícia Pinho e Márcia Faria asseveram que "[P] por vezes encontramos um pensamento de que os requerentes à adoção podem 'experimentar a criança' e, se não gostarem do produto, se ela não corresponder ao filho idealizado, podem desistir da adoção, pois, legalmente, a adoção é irrevogável somente após a sentença do Juiz. Contudo, do ponto de vista psicológico, consideramos que os requerentes, ao levarem a criança para casa sob guarda provisória, estabelecem um compromisso ético em relação à adoção, principalmente nas situações de adoção tardia na qual houve visitações prévias." (LEVY, PINHO, FARIA, 2009, p. 63).
} 
“devolução", que ocorre após o deferimento do pedido adotivo, o que, na verdade, corresponde a abandono do filho. ${ }^{18}$ Identificado o desejo de desistência, por qualquer que seja o motivo, a equipe técnica do Juízo deve atuar com o intuito de compreender as questões envolvidas e intervir para fortalecer os laços que começaram a ser construídos, podendo até fazer encaminhamentos necessários, inclusive para a psicoterapia (KIRCH, COPATTI, 2014, p. 28). Como salienta Maria Luiza Ghirardi (2015, p. 29-30), esses assistentes sociais e psicólogos forenses, que acompanham todo o procedimento de adoção desde a habilitação, devem reavaliar a permanência do adotando sob a guarda dos adotantes, opinando inclusive sobre o término da convivência, se for a melhor medida ao caso.

Citando uma entrevista realizada com uma assistente social da Vara de Infância e Juventude de Passo Fundo, Aline Kitch e Lívia Copatti (2014) afirmam que em ocasiões específicas, como aquelas em que há uma alguma situação de rejeição ou naquelas em que a convivência entre as partes é vista mais como um dever do que um desejo, a desistência pode trazer mais benefícios à criança ou ao adolescente. Em tais situações, pode ser mais benéfico que o ex-adotando "retorne à casa de acolhimento e assim busque-se uma nova família, que tenha em si a compreensão e o carinho necessários para adotar.” (KIRCH, COPATTI, 2014, p. 25). Todavia, essa não costuma ser a regra.

Quando a desistência - e o mesmo vale para a devolução- efetivamente se concretiza, ela pode produzir impactos profundos na vida daquelas crianças e daqueles adolescentes, que podem refletir na capacidade destes de criar laços saudáveis e de se desenvolverem de forma saudável. Maria Luiza Ghirardi ensina que:

\footnotetext{
${ }^{18} \mathrm{O}$ art. 197-E $\S 5^{\circ}$ da Lei n. 8.069/1990, traz a diferenciação entre desistência e devolução. Ismael Souza e Gláucia Souza são críticos ao mencionado dispositivo e afirmam que "[D] duas oportunidades de violação de direitos das crianças e adolescentes através do abandono podem ser geradas durante os procedimentos da adoção, segundo as denominações dadas pelo próprio Estatuto: a primeira é a desistência, que se dá durante o estágio de convivência e a segunda, a devolução, que ocorre após o trânsito em julgado da ação. Ambas, na verdade, se traduzem em uma palavra só: reabandono. Cumpre esclarecer que as terminologias 'desistência' e 'devolução' serão utilizados para compreensão de qual momento da ocorrência de reabandono que estará se tratando (durante ou após o processo de adoção). Contudo, as terminologias não estão corretas, vez que crianças e adolescentes não são mercadorias passíveis de desistência ou devolução, conforme termos utilizados no Direito do Consumidor. O que ocorre, de fato, é um novo abandono.

Quando os adotantes possuem o livre ensejo de dispor da criança ou do adolescente durante o processo de adoção e até mesmo depois, tendo a oportunidade de despojar-se dos mesmos como bem entenderem, podendo reenviálos à instituição de acolhimento, retiramos da população infantojuvenil a Proteção Integral a elas inerentes, a guarida dos princípios acima narrados, bem como o direito a voz e o direito de participação nas decisões sobre a sua própria vida, esculpidos trabalhosamente pela Convenção dos Direitos das Crianças e perpetuados no Estatuto. Faz-se aqui, incontestavelmente, a inconstitucional diferenciação entre a pessoa dos filhos." (SOUZA, SOUZA, 2019, p. 170-171).
} 
[...] devolução assim oficializada é apenas uma entre muitas devoluções possíveis, entendendo-se a devolução como uma experiência que reedita, no psiquismo da criança, outras e antigas vivências ligadas à rejeição e ao abandono. Graças à consideração de que tanto a restituição da criança como a sua devolução são reedições de experiências ligadas ao abandono, este trabalho equipara a restituição prevista em lei à devolução. Guardadas as devidas proporções e diferenças que, sem dúvida, existem no plano legal, mas sobretudo, no âmbito da experiência psíquica da criança, não se pode minimizar a importância da restituição durante o estágio de convivência. Tal conduta poderia representar a naturalização da reincidência presente e, portanto, as consequências advindas dessa medida para a criança devolvida. De qualquer modo, esse movimento retroativo reflete a possibilidade, sempre presente, de ocorrerem retrocessos e vicissitudes em todas as relações de cunho afetivo. (GHIRADI, 2015, p. 20, destaque do autor).

A desistência e a consequente entrega do ex-adotando ao acolhimento revivem a situação de abandono pela qual ele passou com a família natural, podendo sedimentar sentimentos de infelicidade, inadequação e rejeição (CRUZ, 2014, p.20), ou seja, a criança e o adolescente se sentem "culpados pelo insucesso da medida, rejeitados, inseguros, considerando que as relações afetivas não são dignas de confiança." (VERDI, 2019, p. 212-213). ${ }^{19}$ Obviamente, caberá aos técnicos que executam a política pública de acolhimento atuar para auxiliar o acolhido a lidar com tais sentimentos.

Apesar dos danos, muitas vezes irreversíveis, a perda de autoestima e os traumas psicológicos ocasionados pela devolução, é possível pensar, sob outra perspectiva, em como o direito nacional pode responder a essa questão. Se a desistência foi realizada mediante petição nos autos e o adotando só foi entregue à entidade de acolhimento após a revogação judicial da guarda e que ele não foi submetido a maus-tratos ou a vexame ou constrangimentos, não há de se falar em responsabilização administrativa ou penal dos adotantes desistentes. ${ }^{20}$ Porém, a possibilidade de configuração da responsabilidade civil nesse caso merece um exame mais detido.

\footnotetext{
${ }^{19}$ Para a Desembargadora do TJMG, Vanessa Verdolim Andrade (2014a, p. 16), a desistência da adoção pode revitimizar a criança ao fazê-la passar por uma nova situação de abandono. Ela ainda defende que não pode ser aceita a revogação de guarda, ocasionada por essa desistência, que serve para beneficiar os adotandos e não os adotantes, uma vez que nesse caso, a Lei n. 8.069/1990 deixaria "de cumprir seu fim de proteção para ter o objetivo de revitimizar as crianças" (TRIBUNAL DE JUSTIÇA DE MINAS GERAIS, 2014a, p. 17).

${ }^{20}$ Havendo maus-tratos, é configurado crime previsto no art. 136 do Código Penal com penas que variam de detenção de dois meses a um ano até de detenção de quatro a doze anos, dependendo se houve lesão corporal grave ou morte, e a submissão da criança ou do adolescente sob guarda a situações de vexame ou constrangimento configura o ilícito penal constante no art. 232 do Estatuto da Criança e do Adolescente com pena de detenção de seis meses a dois anos. Se a entrega à entidade de acolhimento for realizada antes da decisão judicial de revogação de guarda, essa conduta pode ser enquadrada como descumprimento culposo ou doloso dos deveres inerentes à guarda, que é infração administrativa prevista no art. 249 da Lei n. 8.069/1990 com pena de seis a vinte salários mínimos, aplicada em dobro em caso de reincidência.
} 


\section{REFLEXÕES SOBRE UMA POSSÍVEL RESPONSABILIZAÇÃO CIVIL DOS DESISTENTES DA ADOÇÃO}

A responsabilidade civil, ou responsabilidade extracontratual, é uma das áreas do Direito Civil nacional que mais passou por transformações ao longo do tempo. Construída com base em quatro fundamentos (ato, culpa, dano e nexo de causalidade), como todo Direito privado, ela foi pensada em uma ótica patrimonial e se destinava a reparar danos ocorridos, de modo que aquele que sofreu algum tipo de dano não fosse prejudicado. Por essa razão, sua função era meramente o retorno ao status quo ante, sendo o valor das indenizações calculado com base na teoria da diferença patrimonial, ou seja, o quantum indenizatório seria exatamente a diferença entre o valor do patrimônio antes e depois do advento do ato danoso, sendo vedado assim o enriquecimento sem causa.

A ideia do dano unicamente patrimonial gerou discussões sobre a possibilidade de outros tipos de dano que atingissem outros aspectos da vida civil. A ênfase dada para a promoção e proteção da pessoa trazida pela Constituição da República Federativa do Brasil de 1988 (CRFB/1988) acabou por expandir o escopo da responsabilidade civil, fazendo com que ela atuasse também na esfera não patrimonial do indivíduo. Essa previsão constitucional faz parte dessa nova função do ordenamento jurídico nacional de garantir a máxima proteção à pessoa humana (MORAES, 2003, p. 182). Com isso, esses outros danos passaram a ser abarcados pelo instituto e, dentre esses novos danos, ${ }^{21} \mathrm{o}$ maior destaque foi para a pacificação da antiga controvérsia sobre a existência de um dano unicamente moral. Além da sua identificação com a proteção e promoção do indivíduo, esse tipo de dano tem como peculiaridade a impossibilidade do retorno ao status quo ante, tendo a indenização, nesses casos, um caráter compensatório em vez da reparação do dano sofrido.

Leonardo Bessa e Milla Reis (2020, p. 3) resumem as correntes que se formaram para a conceituação e configuração do dano moral, tendo sido esse tipo de dano relacionado à

\footnotetext{
${ }^{21}$ Não é objetivo desse trabalho traçar todo o desenvolvimento da responsabilidade civil no país. Basta deixar claro que a disciplina desse instituto foi se modificando para buscar assegurar que a vítima não ficasse sem a devida reparação. A título de exemplo, recorde-se que o Código Civil brasileiro de 1916 previa hipóteses de culpa presumida, isto é, ele reconhecia que, em algumas situações, diante da dificuldade de provar a culpa, era justo que o ônus probatório fosse modificado para que as vítimas não fossem obrigadas a suportar o prejuízo. Já no Código Civil de 2002, essas hipóteses foram transformadas em situações de responsabilidade civil objetiva, ou seja, não havia mais a necessidade de provar a culpa. Para saber mais sobre o tema, indica-se a leitura da obra "Novos paradigmas da responsabilidade civil" do professor Anderson Schreiber (2013).
} 
dor psíquica, à lesão a direitos da personalidade ou à ofensa à dignidade humana. ${ }^{22}$ Não se discutirá aqui qual das correntes é a mais indicada para o Direito nacional, sendo que, para fins desse trabalho, qualquer uma das duas últimas correntes pode ser utilizada, já que ambas demonstram preocupação em assegurar o livre e saudável desenvolvimento da pessoa, dentro da qual, como advertem Flávio Tartuce e Giselle Groeninga (2006, p. 150), está a integridade psicofísica. Justamente em razão da nobreza do bem jurídico tutelado pelo dano moral é que se entende que esses danos independem da comprovação, sendo, portanto, in re ipsa.

Tratando-se de desistência da adoção, não há de se falar, a priori, em dano material, uma vez que não há, em princípio, nenhuma questão de fundo patrimonial envolvida. No entanto, a ocorrência de dano moral é, em tese, possível. Ocorrendo lesão à integridade psicofísica por parte dos ex-adotantes, a responsabilização civil é cabível pela lesão em si, sendo desnecessária qualquer análise sobre a desistência. Sobre a responsabilização por dano à integridade psíquica, a questão é tormentosa, podendo se identificar três entendimentos diversos nos tribunais brasileiros, as quais merecem uma análise mais profunda.

\subsection{IMPOSSIBILIDADE DE RESPONSABILIZAÇÃO CIVIL: DIREITO DOS ADOTANTES À DESISTÊNCIA DA ADOÇÃO}

A desistência da adoção como direito dos adotantes foi defendida pelo Desembargador do TJMG Afrânio Vilela no julgamento da Apelação Civil n. 1.0481.12.000289-6/002, em que afirmou que, além de não haver nenhum impedimento legal para adotantes desistirem da adoção, essa possibilidade é legalmente permitida, sendo essa um dos motivos da existência do estágio de convivência. O referido Desembargador assevera que:

a função do estágio de convivência é, justamente, apurar a adaptabilidade da criança ao casal e deste à criança. Logo, os apelados tinham o direito de desistir do processo de adoção daquela criança no decorrer do estágio de convivência e isso não configura qualquer ato ilícito ensejador de dano moral ou material.

\footnotetext{
${ }^{22}$ Entre essas três concepções de dano moral, a primeira delas, a dor psíquica, foi a primeira e é a mais criticada por alguns motivos. Em primeiro lugar, ela é a mais subjetiva de todas e, em tese, impediria qualquer tipo de padronização de quantificação de danos, já que duas pessoas diferentes podem sentir o mesmo dano de formas e intensidades totalmente distintas. Em segundo lugar, não há dano moral quando a pessoa não possui capacidade de entendimento, seja em razão de tenra idade, seja em razão de uma enfermidade psíquica (BESSA, REIS, 2020, p. 3-4), o que enfraquece a proteção da pessoa. Maria Celina de Moraes (2003, p. 192) aponta que a identificação do dano moral com a dor seria incongruente com a aplicação desse tipo de dano para a pessoa jurídica. Ainda assim, ela continua sendo utilizada nos tribunais brasileiros e foi inclusive base para negar a responsabilidade civil no caso de desistência de adoção pela $5^{\mathrm{a}}$ Câmara Cível do TJMG no julgamento da Apelação Cível n. 1.0481.12.000289-6/002.
} 
Entender de forma contrária, além de não possuir respaldo legal, causaria efeito pernicioso nos processos de adoção, afastando os casais que, receosos de sofrerem futuro processo judicial de reparação de danos, sequer se habilitariam a adotar uma criança, deixando de oportunizar aos infantes que sofreram com o abandono a chance de se verem integrados ao seio de uma família, de exercerem o direito de personalidade de filiação e de receberem e darem amor, o que contribui, sobejamente, para seu desenvolvimento como ser humano. (MINAS GERAIS, 2014b, p. 20-21).

O posicionamento exposto possui alguns pontos, no mínimo, incongruentes com o ordenamento jurídico nacional. De fato, ninguém é obrigado a adotar contra a sua vontade, porém, quando os interessados passam por um procedimento de habilitação e recebem a guarda de uma criança no início do estágio de convivência, é inegável que esses adotantes, especialmente enquanto guardiães, possuem deveres com o adotando. ${ }^{23}$ Entender a desistência dos interessados como um direito, inclusive com ares de direito potestativo (que na visão do entendimento colacionado parece corresponder a não ter deveres), é inverter toda a lógica do direito infantojuvenil e, por consequência, da adoção, voltando a privilegiar os interesses dos adultos (ou da família) em detrimento dos interesses da criança e do adolescente. Como abordado anteriormente, o estágio de convivência existe em prol do adotando, e não a favor dos adotantes, como inclusive reconheceu a também Desembargadora do TJMG Hilda Teixeira da Costa em seu voto proferido na mesma Apelação Civil n. 1.0481.12.000289-6/002 e no julgamento da Apelação Cível n. 1.0702.14.059612-4/001. Nesses mesmos votos, a Desembargadora Hilda Teixeira da Costa assevera que não há um direito dos adotantes a devolver os adotandos. (MINAS GERAIS, 2014a, p. 15-16; 2018, p.17-18). Por fim, a mesma Desembargadora conclui que a alegação de exercício regular do direito de desistir "não merece amparo, uma vez que não se pode promover a ‘coisificação' do processo de guarda.” (MINAS GERAIS, 2018, p. 18).

Entendendo que a desistência, por si só, não pode ser tratada como exercício regular do direito, ainda há dúvidas se tal ato poderia ser considerado ilícito. Sobre esse ponto, Andréa Mendes e Kelda Rocha afirmam que, antes da sentença, a devolução das crianças e dos adolescentes para as entidades de acolhimento não seria um ato ilícito porque não existe previsão normativa nesse sentido. (MENDES, ROCHA, 2018, p. 27). Em que pese o entendimento das autoras, essa afirmação não carece de fundamentação jurídica. Como bem se

\footnotetext{
${ }^{23}$ A guarda é um instituto protetivo da criança e do adolescente. Apesar de poder ser revogada a qualquer tempo, essa revogação só deve ser feita quando representar uma "medida que visa a proteger e resguardar os interesses da criança, para livrá-la de eventuais maus tratos ou falta de adaptação com a família, por exemplo, mas não para proteger aqueles maiores e capazes que se propuserem à guarda e depois se arrependeram." (MINAS GERAIS, 2014a, p. 16).
} 
sabe, não é exigida a descrição de condutas para a responsabilização civil como ocorre para a configuração da responsabilidade administrativa e, de forma ainda mais rígida, penal; basta que uma ação ou omissão dolosa ou culposa cause prejuízo a outrem ou viole direito, ou que se exerça um direito de forma manifestamente além dos limites da sua finalidade econômica ou social, da boa-fé ou dos bons costumes, conforme previsto nos arts. 186 e 187 do Código Civil de 2002. Entender a desistência como Andréa Mendes e Kelda Rocha seria o mesmo que afirmar que uma batida de automóvel ou uma agressão física não são passíveis de responsabilização civil, uma vez que não há previsão específica de sua aplicação a essas situações. Cabe ainda frisar que os mencionados dispositivos estão topograficamente inseridos da parte geral do Código Civil brasileiro, sendo, assim, dispensável que a lei preveja que determinado ato enseja responsabilização civil, uma vez que são aplicáveis a todas as áreas do Direito civil.

Deve-se ainda considerar que a desistência da guarda para fins de adoção tem pelo menos uma clara sanção na ordem jurídica nacional, a exclusão dos desistentes do SNA, salvo decisão fundamentada proferida pela autoridade judicial (art. 197-E do Estatuto da Criança e do Adolescente). Destaque-se também que o dispositivo em questão determina que essa exclusão ocorra sem prejuízo a outras sanções existentes no Direito pátrio, por exemplo, a responsabilidade administrativa, civil e penal, dependendo de qual foi a conduta dos desistentes. Se tal ato não fosse legalmente reprovável, por que teria lhe sido imputada uma sanção e deixado claro que não seria a única sanção possível?

Ainda que se defenda um direito de desistência da adoção, seu exercício sofreria limitações como qualquer direito. Como já mencionado, ao exercê-lo, os guardiães não poderiam manifestamente exceder seus limites da boa-fé, dos bons costumes e dos fins econômicos ou sociais. Assim, seria necessário averiguar no caso concreto como se deu o exercício desse direito ou pensar em quais seriam os parâmetros para o seu exercício.

Por fim, o último argumento trazido pelo Desembargador Afrânio Vilela sobre o possível afastamento de adotantes receosos, que poderia representar a não adoção de diversas crianças, é, no mínimo, polêmico. Isso porque, em tese, afastar pretensos adotantes receosos seria algo que a lei deveria fazer. Se existe receio, ainda que seja o de ser eventualmente responsabilizado na esfera civil, esse pretendente deve trabalhar consigo mesmo sobre o que é ser pai ou mãe. É preciso que esses pretendentes compreendam de antemão que, como adverte Bauman (2004, p. 45), dentro do "pacote da paternidade/maternidade" há muitas alegrias, muitas dores e muito temor do que há por vir. 
Pelas razões expostas, este entendimento não parece coadunar com o Direito nacional.

\subsection{IMPOSSIBILIDADE DE RESPONSABILIZAÇÃO CIVIL: DESISTÊNCIA SEMPRE COMO INADAPTAÇÃO MÚTUA}

O segundo entendimento foi encontrado em duas decisões proferidas pela oitava câmara cível do Tribunal do Estado do Rio Grande do Sul (TJRS). No julgamento da Apelação Cível n. 70080332737, a Desembargadora Liselena Ribeiro afirma que:

[...] o Estatuto da Criança e do Adolescente, em seu art. 46, prevê que a adoção será precedida de estágio de convivência, que, nada mais é do que um período de adaptação da criança com a nova família e dessa família com a criança.

No caso, conforme se observa dos relatórios elaborados pela equipe técnica da casa abrigo e Conselho Tutelar juntados com a inicial, o estágio de convivência restou frustrado, seja pelo comportamento das crianças, entendido como inadequado pelos adotantes, ou mesmo por estes não estarem realmente preparados para receber novos membros na família.

Observe-se que, embora esse novo abandono possa, de fato, ocasionar danos às crianças, não há vedação legal para que os futuros pais, ora recorridos, desistam da adoção quando estiverem apenas com a guarda dos menores, sendo importante salientar que o vínculo de adoção somente se constitui através de sentença judicial, conforme previsto no art. 47 do ECA (...) (RIO GRANDE DO SUL, 2019a, p. 7)

O mesmo entendimento foi defendido no voto vencedor proferido pelo Desembargador Ricardo Lins Pastl na Apelação Cível n. 70079126850, que citou literalmente a sentença de primeira instância, sentença esta que havia repetida a citação acima mencionada. O mesmo trecho também foi reafirmado pelo Desembargador Alexandre Kreutz, que também colacionou o mesmo excerto do acórdão da Apelação Cível n. 70080332737 (RIO GRANDE DO SUL, 2019, p. 21-23).

O que chama atenção é que o TJRS compreende o estágio de convivência como um período de adaptabilidade e que, havendo inadaptação, independentemente do motivo, não há vedação legal para a desistência da adoção por parte dos adotantes, ainda que gere danos à criança. Os dois acórdãos também possuem em comum o curto lapso temporal de estágio de convivência, respectivamente, quarenta e cinco dias e catorze dias.

Esse entendimento possui alguns equívocos. O primeiro deles é que coloca a parte que deve ser protegida em situação de desproteção. Isso porque, ao não examinar as circunstâncias do caso concreto, os dois julgados acabam desresponsabilizando os ex-adotantes de eventual agravamento dos danos causados pelo reabandono. Ao entender que não importa o motivo ou o comportamento daqueles que desistem da guarda e, como consequência, da adoção, o TJRS 
dá carta branca para os adultos agirem como quiserem e não zelarem pelo dever de cuidado que deve ser inerente ao instituto protetivo e promocional da guarda. Isso fica ainda mais claro quando se lê o primeiro acórdão.

A Apelação Cível n. 70080332737 versa sobre a desistência da adoção de duas crianças que já haviam passado por um insucesso anterior de adoção. A equipe técnica que trabalhou no caso teve toda cautela para a nova tentativa de adoção, tendo, inclusive, feito um período prévio de aproximação de quatro meses, antes de concordar com a concessão da guarda. O relatório do Conselho Tutelar, mencionado no excerto colacionado, narrou que a adotante reclamava da má postura das crianças na escola, o que se verificou inverídico, e que o adotante tinha um comportamento grosseiro com os adotandos. (RIO GRANDE DO SUL, 2019a, p. 4-6). Já na Apelação Cível n. 70079126850, em seu voto vencido, o Desembargado Rui Portanova reconheceu que não há ilícito na desistência dos adotantes quando a adoção não é aconselhada em razão de uma "frustração legítima", ou seja, quando ocorre a não adaptação mútua, apesar do esforço dos adotantes. O mesmo Desembargador pontuou que os adotantes recusaram o atendimento técnico e que eles não agiram de forma cautelosa e compromissada com o múnus da guarda. (RIO GRANDE DO SUL, 2019b, p. 5-6).

Nessas decisões, a total desconsideração do caso concreto premiou comportamentos, no mínimo, não condizentes com os princípios da Proteção Integral por parte dos adotantes e vulnerabilizou as crianças, justamente o que o ordenamento jurídico brasileiro e internacional busca evitar. Isso não quer dizer que, iniciado o procedimento de adoção, os adotantes sejam obrigados a concluir o processo e se tornar pais. ${ }^{24}$ Pelo contrário, em algumas situações, como em caso de rejeição insuperável, é melhor que a adoção não seja mesmo concluída. O que se exige é que durante todo o contato com a criança e/ou com o adolescente, os adotantes ajam com cuidado e respeito, zelando pelos direitos infantojuvenis e cumprindo satisfatoriamente os deveres impostos pela guarda até que esta seja judicialmente revogada.

Em relação à inexistência de ato ilícito, todas as considerações feitas no tópico anterior são aqui também válidas, permanecendo a reflexão: se não há proibição, por que é prevista sanção de exclusão do CNA que só não seria aplicada se ela fosse fundamentadamente afastada

\footnotetext{
${ }^{24}$ Volta-se a frisar que não ocorrendo a adaptação mútua "não é ilegal que a criança ou adolescente seja retornado para a instituição de abrigo sem qualquer penalidade para os candidatos a adotante (sic)." (MENDES; ROCHA, 2018, p. 23). O que se objetiva aqui é averiguar se a conduta dos ex-adotantes causou danos além daqueles decorrentes do insucesso natural à adoção.
} 
em uma decisão judicial? Por que a norma expressamente menciona sem prejuízo a outras sanções? E mais: quais seriam os fundamentos capazes de afastar essa sanção?

Nota-se que esse entendimento também não se mostra mais adequado aos ditames do Direito nacional.

\subsection{POSSIBILIDADE DE RESPONSABILIDADE CIVIL: A ANÁLISE DO CASO} CONCRETO

O último entendimento judicial sobre a aplicação da responsabilidade civil aos casos de desistência de adoção defende que o ato de desistir da adoção em si não é necessariamente ilícito, mas as particularidades do caso concreto podem levar à responsabilização civil. O TJMG expressamente pronunciou-se dessa forma no julgamento das Apelações Cíveis n. 1.0024.11.049157-8/002 e n. 1.0194.12.007673-3/001. Nesse segundo julgado, o Desembargador Luís Carlos Gambogi afirmou que:

[...] não há a vedação legal para que os pretensos pais adotivos desistam da adoção. Apesar disso, estou em que se deve averiguar caso a caso os motivos apontados na hipótese de desistência, uma vez que o Judiciário não pode coadunar com as aventuras e tentativas irresponsáveis de adoção. (MINAS GERAIS, 2015, p. 14).

O TJMG, em outros dois julgados, e o Tribunal de Justiça do Estado da Paraíba (TJPB), em uma decisão, reconheceram a possibilidade de responsabilização civil dos adotantes desistentes. ${ }^{25} \mathrm{O}$ que chama atenção nesses julgados é que eles também analisam as peculiaridades dos casos em vez de se prenderem somente à discussão abstrata da análise do texto legal. Com isso, esses julgados parecem ser mais adequados ao Direito civil brasileiro atual, que busca, justamente, a promoção da justiça ao caso concreto.

Todos eles partem de um mesmo ponto: a guarda para fins de adoção gera deveres aos pretensos adotantes. Como já tratado, a guarda é um instituto iminentemente protetivo e promocional, e os guardiães têm o dever de prestar toda a assistência educacional, material e moral aos pupilos (art. 33 da Lei n. 8.069/1990) com o objetivo de assegurar a eles o

\footnotetext{
${ }^{25}$ Em 2014, no julgamento da Apelação Cível n. 1.0481.12.000289-6/002, o TJMG reconheceu a possibilidade de utilização da responsabilidade civil, mas, diante do caso concreto, decidiu pela não ocorrência de dano. Em 2018, o mesmo TJMG, no julgamento da Apelação Cível n. 1.0702.14.059612-4/001, decidiu pela ocorrência de dano moral na desistência da adoção em razão do comportamento negligente e imprudente dos desistentes. Em 2020, no julgamento da Apelação Cível n. 0001378-37.2018.8.15.0011, o TJPB também decidiu pela responsabilização civil dos adotantes, que, agindo de forma imprudente, desistiriam da adoção.
} 
desenvolvimento completo e saudável. Dessa forma, ao interpretar esses deveres, é importante entender que se aplicam aos guardiães outros institutos existentes no ordenamento jurídico brasileiro, como a boa-fé ou o dever de cuidado.

A aplicação da boa-fé às relações familiares não é unanimidade na literatura jurídica nacional, ${ }^{26}$ mas os tribunais estaduais brasileiros admitem sua aplicação. ${ }^{27}$ Especificamente sobre o tema deste trabalho, a lesão à boa-fé objetiva foi utilizada como base para admissão da responsabilidade civil no julgamento da Apelação Cível n. 1.0194.12.007673-3/001. ${ }^{28}$ Todavia, ainda que possa se discutir a aplicação ou não do princípio da boa-fé, não se discute que o dever de cuidado é imposto a qualquer um que cuide de uma pessoa vulnerável (criança, adolescente, idoso, pessoa com deficiência, etc.). ${ }^{29}$

Embora as decisões não mencionem expressamente os parâmetros utilizados para analisar se o ato de desistência seria ou não ilícito, é possível depreender alguns critérios que podem servir de base para o exame da responsabilidade civil nesses casos: o motivo, o modo e o tempo de convívio. Por vezes, apenas um deles poderá, por si só, demonstrar a necessidade da responsabilização civil, e quanto mais aspectos negativos puderem ser identificados nesses critérios, mais evidente fica a ilicitude da desistência.

\subsubsection{Motivo}

\footnotetext{
${ }^{26}$ Anderson Schreiber é um dos autores que vê com ressalvas a aplicação da boa-fé objetiva às relações familiares existenciais. Para ele, a aplicação desse princípio tende a aproximar as situações existenciais das relações patrimoniais, sendo que existem outros mecanismos dentro do direito das famílias que melhor justificariam as decisões judiciais.

${ }^{27}$ Em 2020, no julgamento da Apelação Cível n. 0020943-85.2018.8.19.0007, o Tribunal do Estado do Rio de Janeiro expressamente decidiu que o princípio da boa-fé objetiva também é aplicável às relações familiares. (RIO DE JANEIRO, 2020).

${ }^{28}$ Essa mesma decisão entendeu que a desistência naquele caso também configurou abuso de direito. (MINAS GERAIS, 2015, p. 17).

${ }^{29} \mathrm{O}$ dever de cuidado foi reconhecido pelo STJ no julgamento do REsp. n. 1.159.242/SP no qual a Ministra Nancy Andrighi reconheceu a configuração de dano moral pelo não cumprimento desse dever, compreendendo que este decorre do poder familiar, ainda que não expressamente previsto no Código Civil. O Desembargador do TJMG Marcelo Rodrigues (2014), no voto proferido no julgamento da Apelação Cível n. 1.0481.12.000289-6/002, afirmou que a desistência da adoção violou o direito fundamental à convivência familiar do adotante e o princípio da paternidade responsável. Sobre a aplicação do princípio da paternidade responsável, mesmo não havendo relação de parentalidade, ele explicou que "[A] a responsabilidade parental, a fim de que alcance seus reais efeitos e de fato proteja as crianças e adolescentes, há que ser entendida em um sentido mais amplo. Assim, este princípio deve ser aplicado a todos os que figurem no papel dos pais biológicos, exercendo atributos do poder familiar. Os que exercerem a guarda (mesmo de fato), os tutores e adotantes têm de se submeter a este princípio." (MINAS GERAIS, 2014b, p. 24). Dessa forma, o dever de cuidado é aplicável à guarda de terceiros, seja por via indireta, conforme pode se entender do entendimento do Desembargador Marcelo Rodrigues, seja de forma direta, quando se entende que esse dever é decorrência do sistema de proteção dos direitos infantojuvenis.
} 
No curso do estágio de convivência, diversos motivos poderão surgir para que haja a desistência da adoção, devendo eles serem analisados com muita cautela. A inadaptação, já mencionada, é o principal motivo, senão o único que justifica a desistência da adoção. Havendo um real esforço na construção do vínculo materno/paterno-filial, inclusive com busca do apoio da equipe técnica ou outros profissionais, uma relação pautada no cuidado e no respeito e ainda assim não se verificar a formação de laços, a desistência é tida como bem motivada. Nessa situação, não há de se falar em ilicitude da desistência nem da aplicação da sanção prevista no art. 197-E do Estatuto da Criança e do Adolescente. ${ }^{30}$

Ismael de Souza e Gláucia de Souza (2019, p. 180) defendem que deveriam ser discriminados na lei os motivos pelos quais seria permitida a desistência da adoção. Em que pese o entendimento dos autores, a previsão não existe justamente porque, em tese, não há essa permissão. Como exposto anteriormente, a única justificativa plausível seria a não adaptação das partes. Qualquer outro motivo deve levar às sanções legais, inclusive à responsabilidade civil.

Os motivos apontados para a desistência da adoção são os mais diversos. Os autores que trabalham a temática apontam alguns deles, como a descoberta posterior de doenças (BERTONCINI, CAMPIDELLI, 2019, p. 83/84) e o mau comportamento dos adotandos (LEVY, PINHO, FARIA, 2009, p. 61; BERTONCINI, CAMPIDELLI, 2019, p. 94; VERDI, 2019, p. 207). Nos julgados analisados, os motivos para a desistência foram a descoberta de uma enfermidade (MINAS GERAIS, 2012, p. 3-5), o nascimento de posterior um filho biológico, disfarçado de ameaça à integridade física dos adotantes (MINAS GERAIS, 2018, p. 14), e o cometimento de pequenos furtos (MINAS GERAIS, 2015, p. 14).

O que há em comum a todas essas causas é que elas são faces de um motivo mais amplo, a quebra das expectativas. Quando essas expectativas não foram devidamente superadas, o que deveria ser feito ainda na fase de habilitação (conforme ressaltado no tópico 3), ocorre o choque entre a figura do filho esperado com a criança real (CRUZ, 2014, p. 20). Maria Luiza Ghirardi (2015, p. 34 e 123) afirma que a idealização desconsidera qualquer conflito possível, mas o surgimento das individualidades da criança ou do adolescente fazem com que esses conflitos apareçam. Esses comportamentos diferentes do desejado passam a ser fontes de conflitos e eles

\footnotetext{
${ }^{30}$ Nesse sentido, o Tribunal de Justiça do Estado de Santa Catarina (TJSC), no julgamento da Apelação Cível n. 0900487-80.2016.8.24.0020 e do Agravo de Instrumento n. 4029762-57.2017.8.24.0000 reconheceu em ambos os casos que o adotando tomou todas as medidas necessárias para tentar a consolidação dos vínculos, que houve busca pelo acompanhamento psicológico e que não houve indícios de conduta negligente. Por essas razões, as duas decisões reconheceram que não houve ato ilícito.
} 
costumam ser atribuídos à origem biológica (LEVINZON, 2006, p. 26-27), fazendo com que muitas vezes os adotantes desistam daquela relação (BERTONCINI, CAMPIDELLI, 2019, p. $82)$.

Nessas situações, não há, na verdade, motivo para a devolução, uma vez que conflitos intergeracionais fazem parte da vida de qualquer um. Saber lidar com essas situações adversas, que ocorrerão muitas vezes ao longo da vida familiar, é parte da paternidade/maternidade (MINAS GERAIS, 2018, p. 18). Assim, não havendo justificativa válida, Simone Verdi é incisiva ao afirmar que "a conduta dos adotantes de desistir do processo imotivadamente durante o estágio de convivência é ilícita uma vez que viola os direitos fundamentais da criança que permanecia em sua guarda.” (VERDI, 2019, p. 208). A responsabilidade dos adotantes para com os adotandos nos casos de desistência imotivada foi reconhecida pela Desembargadora do TJMG Hilda Teixeira da Costa nos julgamentos dos recursos de Apelação Civil 1.0481.12.000289-6/002 e de Agravo na mesma Apelação Cível (1.0481.12.000289-6/001).

Entender que os pretensos adotantes podem desistir imotivadamente do pedido é colocar o adotando novamente em posição totalmente passiva, é tratá-lo como objeto de intervenção como fazia o antigo Direito do menor. Isso não quer dizer que esses pretensos adotantes são obrigados a concluir a adoção contra a sua vontade, especialmente quando não se formou laços de afeto, mas que eles têm o dever de proceder de forma cuidadosa e menos traumática possível para o adotando, inclusive como decorrência do dever guarda que foi a eles atribuídos. ${ }^{31}$ Isso sim seria considerar a criança como sujeito de direitos.

\subsubsection{Modo}

Outro parâmetro que se observa é o modo como é feita a desistência da guarda para fins de adoção. Como já abordado, o que se espera dos adotantes é que, nos primeiros sinais de conflito ou inadaptação, eles busquem a ajuda técnica para que sejam trabalhadas as fragilidades e sejam reforçados os laços de convivência que estão se formando. Quando isso não acontece, essa "falha" pode representar tanto uma subestimação de uma questão como um primeiro sinal de negligência por parte dos adotantes, por isso é necessário o exame mais detido das outras circunstâncias do caso concreto.

\footnotetext{
${ }^{31}$ O Desembargador do TJRS Rui Portanova, em seu voto vencido proferido no julgamento da Apelação Cível n. 70079126850, entendeu que a desistência imotivada configura abuso do direito de adotar e deve, portanto, ensejar reparação civil.
} 
Porém, quando a desistência se dá de forma abrupta, ainda que a relação entre adotantes e adotando já esteja conflituosa, Simone Verdi (2019, p. 209) defende a aplicação da responsabilidade civil, especialmente se essa desistência também for imotivada. Nesse sentido, o TJMG (julgamento das apelações cíveis n. 1.0024.11.049157-8/002 e 1.0481.12.0002896/002) e o TJPB (Apelação Cível n. 0001378-37.2018.8.15.0011) reconheceram que a conduta dos pretensos pais é passível de responsabilização civil. (MINAS GERAIS, 2014a, p. 17; 2014b, p. 16; PARAÍBA, 2020, p. 8).

Epaminondas Costa (2009, p. 166-169) defende que quando os adotantes induzem grandes expectativas no adotando, passando até a chamá-lo por outro prenome, por exemplo, e comunicam a desistência, esse ato é ainda mais reprovável. O autor conclui que atos assim violam o sistema de proteção dos direitos da criança, e seus autores devem ser responsabilizados.

De fato, a desistência abrupta, sem ao menos buscar proporcionar à criança e ao adolescente acompanhamento psicológico necessário para prepará-los para ruptura com o intuito de diminuir os traumas dessa desistência é, a priori, um descumprimento do dever de cuidado. Um rompimento abrupto é capaz de causar danos psicológicos que vão além daqueles que decorreriam da inadaptação e, aliados a outras particularidades, poderiam ser passíveis de responsabilização civil. Já o contrário denotaria a preocupação e o cuidado dos adotantes e seria motivo suficiente para afastar a responsabilidade civil, como reconheceu o TJSC nos já mencionados julgamentos da Apelação Cível n. 0900487-80.2016.8.24.0020 e do Agravo de Instrumento n. 4029762-57.2017.8.24.0000. (SANTA CATARINA, 2017; 2019).

\subsubsection{Tempo}

Quando se pensa em crianças e adolescentes, o tempo é um fator muito importante.1 A infância e a adolescência é um período de dezoito anos, que corresponderia por volta de um quarto da vida de uma pessoa, considerando que a média de vida de um brasileiro é cerca de setenta anos. Essa fase da vida pode ser pensada em períodos de seis anos, sendo a infância subdivida em primeira infância (zero a seis anos) e segunda infância (seis a doze anos) e a adolescência (doze a dezoito anos). Embora "curta", essa fase é essencial para a formação da personalidade de cada pessoa, já que, especialmente durante a infância, há o desenvolvimento das estruturas neurais e das capacidades cognitivas e é também o momento que crianças desenvolvem a habilidade de formar laços pessoais de confiança que serão a base de uma personalidade saudável (BOWLBY, 1982, p. 98). Logo, quanto mais tempo uma criança passa 
sem ter uma figura de confiança, maior será a chance dela não conseguir desenvolver relações baseadas nesse sentimento no futuro.

O passar do tempo serve para fortalecer os vínculos e consolidar as situações. Durante o estágio de convivência, o passar de meses e até de anos cria expectativas plausíveis de que aquela situação familiar ainda provisória, pelo menos enquanto pendente a decisão sobre a adoção, vai perdurar. Especialmente quando se busca analisar a questão pelo prisma da criança, que é imprescindível dentro do sistema de proteção dos direitos da criança e do adolescente, aquela situação paterno/materno-filial, em regra, vira uma relação consolidada quanto mais o tempo passa. O rompimento dessa situação é um evento traumático, cujos danos tendem a ser maiores quanto maior for o tempo de convivência com os adotantes desistentes.

As decisões que reconheceram a responsabilidade civil dos adotantes desistentes têm como peculiaridade um longo período de convivência entre estes e o adotando. Nos acórdãos proferidos pelo TJMG, nota-se nas apelações cíveis ns. 1.0481.12.000289-6/002 e 1.0194.12.007673-3/001 que os adotandos estavam sob guarda dos requerentes havia mais de três anos (MINAS GERAIS, 2014b; 2015), e nos autos ns. 1.0024.11.049157-8/002 e 1.0702.14.059612-4/001 esse período era superior a um ano (MINAS GERAIS, 2014a; 2018). Já na decisão proferida pelo TJPB, o caso versava sobre duas crianças, de três e seis anos, que estavam na guarda dos postulantes havia mais de três anos. (PARAÍBA, 2020).

$\mathrm{Na}$ tentativa de acabar com esses longos estágios de convivência é que a Lei n. 13.509/2017 alterou o art. 46 caput e incluiu o $\$ 2^{\circ}$-A no mesmo dispositivo do Estatuto da Criança e do Adolescente, fixando o prazo de noventa dias, prorrogável por igual período por decisão judicial fundamentada para o estágio de convivência na adoção nacional. Assim, a tendência é que pelo menos essa questão temporal não se torne mais um parâmetro.

O motivo, o modo e o tempo se mostraram parâmetros úteis para a decisão de cabimento ou não da responsabilidade civil nas decisões que entenderam ser possível a aplicação desse instituto no caso de desistência da adoção. Como dito anteriormente, eles poderiam, por si só, já determinar se seria ou não caso de compensação civil, e quanto mais esses critérios se mostrem desfavoráveis, mais clara se torna a necessidade dessa responsabilização.

\section{CONCLUSÃO}

A inserção da adoção no Direito da Criança e do Adolescente significou a aplicação de uma sistemática e principiologia próprias para o atendimento dos interesses infantojuvenis. 
Com isso, a adoção deixou de ser um instituto jurídico voltado para os interesses dos adultos e passou a focar na criança e no adolescente. Para cumprir essa finalidade, é necessário que sejam observadas as disposições do Estatuto da Criança e do Adolescente para a concretização da adoção, em especial o período de habilitação, com o intuito de gerir as expectativas dos adotantes e de afastar pessoas que não estão aptas para adotar, e o estágio de convivência.

Ressalta-se que o estágio de convivência não é um período de teste, sujeito a arrependimento, e sim um compromisso assumido pelos adotantes perante o Poder Judiciário, além de obrigações de natureza ético-jurídicas com o adotando.

Caso ocorra a desistência da adoção durante esse período por ato de vontade dos adotantes e havendo formação de vínculos afetivos entre adotantes e adotando, essa conduta pode acarretar danos à saúde psíquica da criança ou do adolescente, podendo, portanto, ocorrer a responsabilização civil dos adotantes. Em análise de determinados julgados dos tribunais brasileiros, observou-se três possibilidades, das quais duas se mostraram incompatíveis com os preceitos do Direito da Criança e do Adolescente: a existência de um direito dos adotantes de desistência da adoção e a desistência considerada sempre como sendo uma inadaptação mútua. A terceira possibilidade considera viável a responsabilização civil dos adotantes pela desistência da guarda para fins de adoção, desde que sejam observadas as peculiaridades do caso concreto, em especial, o motivo da desistência, o modo como foi feita e o tempo de guarda do adotando.

\section{REFERÊNCIAS}

BAUMAN, Zygmunt. Amor líquido: sobre a fragilidade dos laços humanos. Rio de Janeiro: Jorge Zahar, 2004.

BERTONCINI, Carla; CAMPIDELLI, Laísa Fernanda. Análise sobre a devolução da criança e do adolescente no processo de adoção: danos psicológicos e a possibilidade de responsabilidade civil. Revista de Direito de Família e Sucessão, Porto Alegre, v. 4, n. 2, p. 78 - 98, Jul. /Dez. 2018.

BESSA, Leonardo Roscoe; REIS, Milla Pereira Primo. Dano moral e dor: direito autônomo à integridade psíquica. Civilistica.com. Rio de Janeiro, a. 9, n. 1, 2020. Disponível em: <http://civilistica.com/dano-moral-e-dor/>. Acesso em: 10 ago. 2020.

BOWLBY, John. Formação e rompimento dos laços afetivos. Tradução Álvaro Cabral. São Paulo: Martins Fontes, 1982. 
BRASIL. Superior Tribunal de Justiça. (3. Turma). Recurso Especial n. 1.159.242/SP. Civil e Processual Civil. Família. Abandono afetivo. Compensação por dano moral. Possibilidade. [...] Rel. Min. Nancy Andrighi. Brasília, 24 abr. 2012. Disponível em: $<\mathrm{https}$ ://ww2.stj.jus.br/processo/revista/documento/mediado/?componente=ITA\&sequencial= $1067604 \&$ num_registro $=200901937019 \&$ data $=20120510 \&$ formato $=P D F>$. Acesso em: 28 ago. 2020.

CARNAÚBA, Géssica da Silva; FERRET, Jhainieiry Cordeiro Famelli. Devolução de crianças adotadas: consequências psicológicas causadas na criança que é devolvida durante o estágio de convivência. Revista Uningá, Maringá, v. 55, n. 3, p. 119-129, jul./set. 2018.

COSTA, Epaminondas da. Estágio de convivência, "devolução" imotivada em processo de adoção de criança e de adolescente e reparação por dano moral e/ou material. In: CONGRESSO NACIONAL DO MINISTÉRIO PÚBLICO: o Ministério Público como fator de redução de conflitos e construção da paz social. 18., 2009, Florianópolis-SC. Livro de teses [...]. Associação Catarinense do Ministério Público - ACMP. Porto Alegre: Magister, 2009, p. 166-171.

CRUZ, Sabrina D’Avila da. A frustração do reabandono: uma nova ótica acerca da devolução em processos de adoção. Artigo Científico (Curso de Pós Graduação) - Escola da Magistratura do Estado do Rio de Janeiro, Rio de Janeiro, 2014.

GAGLIANO, Pablo Stolze; BARRETTO, Fernanda Carvalho Leão. Responsabilidade civil pela desistência na adoção. Instituto Brasileiro de Direito de Família. 27 ago. 2020.

Disponível em:

$<$ https://ibdfam.org.br/artigos/1513/Responsabilidade+civil+pela+desist\%c3\%aancia+na+ado $\%$ c3\%a7\%c3\%a3o>. Acesso em:

GHIRARDI, Maria Luiza de Assis Moura. Devolução de crianças adotadas: um estudo psicanalítico. São Paulo: Primavera Editorial, 2015.

KIRCH, Aline Taiane; COPATTI, Lívia Copelli. Criança e adolescente: a problemática da adoção e posterior devolução às casas de acolhimento. Prisma Jur., São Paulo, v. 13, n. 1, p. 13-36, jan./jun. 2014.

LEVINZON, Gina Khafif. A adoção na clínica psicanalítica: o trabalho com os pais adotivos. Mudanças - Psicologia da Saúde, v. 14, n. 1, jan-jun 2006, p. 24-31.

MENDES, Andréa Martins; ROCHA, Kelda Sofia da Costa Santos Caires. Adoção frustrada: a responsabilidade civil em face da devolução da criança ou adolescente. Revista da ESMAM, São Luís, v.12, n.14, jul./dez. 2018, p. 19-51.

MINAS GERAIS. Tribunal de Justiça. (2a Câm. Cível). Processo: Agravo de instrumento em ACP n. 1.0481.12.000289-6/001. Rel. Des.(a) Hilda Teixeira da Costa. Belo Horizonte, 23 out. 2012. Disponível em:

<https://www5.tjmg.jus.br/jurisprudencia/pesquisaNumeroCNJEspelhoAcordao.do;jsessionid $=8285$ C4C7AC5AC9D0429A7139DAD613FB. juri_node2 $?$ numeroRegistro $=1 \&$ totalLinhas $=$ $1 \&$ linhasPorPagina $=10 \&$ numeroUnico $=1.0481 .12 .000289$ -

6\%2F001\&pesquisaNumeroCNJ=Pesquisar>. Acesso em: 28 ago. 2020. 
MINAS GERAIS. Tribunal de Justiça. (1a Câm. Cível). Processo: AC 1.0024.11.0491578/002. Rel. Des.(a) Des.(a) Vanessa Verdolim Hudson Andrade. Belo Horizonte, 15 abr. 2014a. Disponível em:

<https://www5.tjmg.jus.br/jurisprudencia/pesquisaNumeroCNJEspelhoAcordao.do;jsessionid $=8285$ C4C7AC5AC9D0429A7139DAD613FB.juri_node2 numeroRegistro $=1 \&$ totalLinhas $=$ $1 \&$ linhasPorPagina $=10 \&$ numeroUnico $=1.0024 .11 .049157$ -

8\%2F002\&pesquisaNumeroCNJ=Pesquisar>. Acesso em: 28 ago. 2020.

MINAS GERAIS. Tribunal de Justiça. (5a Câm. Cível). Processo: AC 1.0481.12.0002896/002. Rel. Des.(a) Hilda Teixeira da Costa. Belo Horizonte, 12 ago. 2014b. Disponível em: <https://www5.tjmg.jus.br/jurisprudencia/pesquisaNumeroCNJEspelhoAcordao.do;jsessionid =1388A11C4AC701F8432BB3A3712BCBC5.juri_node2?numeroRegistro=1\&totalLinhas=1 \&linhasPorPagina $=10 \&$ numeroUnico $=1.0481 .12 .000289$ -

6\%2F002\&pesquisaNumeroCNJ=Pesquisar>. Acesso em: 28 ago. 2020.

MINAS GERAIS. Tribunal de Justiça. (5a Câm. Cível). Processo: AC 1.0194.12.0076733/001. Direito Processual Civil. Rel. Des.(a) Luís Carlos Gambogi. Belo Horizonte, 10 set. 2015. Disponível em:

<https://www5.tjmg.jus.br/jurisprudencia/pesquisaNumeroCNJEspelhoAcordao.do;jsessionid $=8285$ C4C7AC5AC9D0429A7139DAD613FB.juri_node2 ?numeroRegistro $=1 \&$ totalLinhas $=$ $1 \&$ linhasPorPagina $=10 \&$ numeroUnico $=1.0194 .12 .007673$ -

3\%2F001\&pesquisaNumeroCNJ=Pesquisar>. Acesso em: 28 ago. 2020.

MINAS GERAIS. Tribunal de Justiça. (2a Câm. Cível). Processo: AC 1.0702.14.0596124/001. Rel. Des.(a) Caetano Levi Lopes. Belo Horizonte, 23 jul. 2018. Disponível em: $<$ https://www5.tjmg.jus.br/jurisprudencia/pesquisaNumeroCNJEspelhoAcordao.do;jsessionid =B9A23151FE9055E54AE11A827FB0BBFE.juri_node1?numeroRegistro=1\&totalLinhas=1 \&linhasPorPagina $=10 \&$ numeroUnico $=1.0702 .14 .059612$ -

4\%2F001\&pesquisaNumeroCNJ=Pesquisar> Acesso em: 28 ago. 2020.

MORAES, Maria Celina Bodin de. Danos à pessoa humana: uma leitura civil-constitucional dos danos morais. Rio de Janeiro: Renovar, 2003.

NAKAMURA, Carlos Renato. Criança e adolescente: sujeito ou objeto da adoção? Reflexões sobre menorismo e proteção integral. Revista Serviço Social \& Sociedade, São Paulo, n. 134, p. 179-197, jan./abr. 2019.

PARAÍBA. Tribunal de Justiça. (1a Câm. Cível). Processo: AC 0001378-37.2018.8.15.0011. Rel. Des.(a) José Ricardo Porto. Teresina, 03 mar. 2020. Disponível em: <http://tjpbjurisprudencia-dje.tjpb.jus.br/dje/2020/3/6/e53e91d1-ee94-47fe-94ee-761d697b06a6.pdf>. Acesso em: 28 ago. 2020.

RIEDE, Jane Elisabete Riede; SATORI; Giana Lisa Zanardo. Adoção e os fatores de risco: do afeto à devolução das crianças e adolescentes. Revista Perspectiva, Erechim. v.37, n.138, p.143-154, junho/2013.

RIO DE JANEIRO. Tribunal de Justiça. (8a Câm. Cível). Processo: AC 0020943 85.2018.8.19.0007. Rel. Des.(a) Teresa de Andrade Castro Neves. Rio de Janeiro, 18 jul. 2020. Disponível em:

<http://www4.tjrj.jus.br/ejud/ConsultaProcesso.aspx? $\mathrm{N}=2020.001 .08807>$. Acesso em: 28 ago. 2020. 
RIO GRANDE DO SUL. Tribunal de Justiça. (8a Câm. Cível). Processo: AC 70080332737. Ação Civil Pública. Rel. Des.(a) Liselena Schifino Robles Ribeiro. Porto Alegre, 28 fev. 2019a. Disponível em:

$<$ https://www1.tjrs.jus.br/site_php/consulta/consulta_processo.php?nome_comarca=Tribunal $\% 20 \mathrm{de} \% 20 \mathrm{Justi} \% \mathrm{C} 3 \% \mathrm{~A} 7 \mathrm{a} \% 20 \mathrm{do} \% 20 \mathrm{RS} \& \mathrm{versao}=\&$ versao_fonetica $=1 \&$ tipo $=1 \&$ id_comarca $=700 \&$ num_processo_mask=\&num_processo=70080332737\&codEmenta=7706337\&temIntT eor=true>. Acesso em: 28 ago. 2020.

RIO GRANDE DO SUL. Tribunal de Justiça. (8a Câm. Cível). Processo: AC 70079126850. Rel. Des.(a) Rui Portanova. Porto Alegre, 04 abr. 2019b. Disponível em:

$<$ https://www1.tjrs.jus.br/site_php/consulta/consulta_processo.php?nome_comarca=Tribunal $\% 20 \mathrm{de} \% 20 \mathrm{Justi} \% \mathrm{C} 3 \% \mathrm{~A} 7 \mathrm{a} \% 20 \mathrm{do} \% 20 \mathrm{RS} \& \mathrm{versao}=\&$ versao_fonetica $=1 \&$ tipo=1\&id_comarca $=700 \&$ num_processo_mask=\&num_processo=70079126850\&codEmenta=7706337\&temIntT eor=true >. Acesso em: 28 ago. 2020.

SANTA CATARINA. Tribunal de Justiça. (4a Câm. Cível). Processo: AC $0900487-$ 80.2016.8.24.0020. Rel. Des.(a) Rodolfo C. R. S. Tridapalli. Florianópolis, 07 dez. 2017. Disponível em: <https://tj-sc.jusbrasil.com.br/jurisprudencia/532330646/apelacao-civel-ac9004878020168240020-criciuma-0900487-8020168240020/inteiro-teor-532330718>. Acesso em: 28 ago. 2020.

SANTA CATARINA. Tribunal de Justiça. (2a Câm. Cível). Processo: Agravo $4029762-$ 57.2017.8.24.0000. Des.(a) Rubens Schulz. Florianópolis, 26 abr. 2019. Disponível em: <https://tj-sc.jusbrasil.com.br/jurisprudencia/574139580/agravo-de-instrumento-ai40297625720178240000-lages-4029762-5720178240000>. Acesso em: 28 ago. 2020.

SCHREIBER, Anderson. Princípio da boa fé objetiva no direito de família. In: CONGRESSO BRASILEIRO DE DIREITO DE FAMÍLIA, 5. 2005, Belo Horizonte, MG. Anais [...] Belo Horizonte: IBDFAM, 2005. Disponível em:

$<$ http://www.ibdfam.org.br/publicacoes/anais/detalhes/714/V\%20Congresso\%20Brasileiro\%2 0de\%20Direito\%20de\%20Fam\%C3\%ADlia>. Acesso em: 10 ago. 2020.

SILVA, José Luiz Mônaco da. A família substituta no estatuto da criança e do adolescente. São Paulo: Saraiva, 1995.

SOUZA, Vanessa Ribeiro Corrêa Sampaio. Sanções decorrentes da irresponsabilidade parental: para além da destituição do poder familiar e da responsabilidade civil.

Civilistica.com. Rio de Janeiro, a. 2, n. 2, abr.-jun./2013. Disponível em:

<http://civilistica.com/sancoes-decorrentes-da-irresponsabilidade-parental/>. Acesso em: 23 ago. 2020 .

SOUZA, Ismael Francisco de; SOUZA, Glaucia Martinhago Borges Ferreira de. A necessidade de um novo olhar sobre os reabandonos de crianças e adolescentes na adoção: a teoria da perda de uma chance e a sua (não) aplicação na Justiça brasileira. Revista Direito \& Paz, São Paulo, SP - Lorena, Ano XI, n. 40, 1 sem. 2019, p. 162-182.

TARTUCE, Flávio; GROENINGA, Giselle Câmara. Dano a integridade psíquica. uma análise transdisciplinar. In: DELGADO, Mário Luiz; ALVES, Jones Figueirêdo. Questões controvertidas: Responsabilidade civil. Série Grandes Temas de Direito Privado, v.5. São Paulo: Método, 2006, p. 141-165. 
MINAS GERAIS. Adoção de Crianças e Adolescentes. TJMG. Disponível em: <https://www.tjmg.jus.br/portal-tjmg/servicos/adocao.htm\#.Xvn0SihKjIU>. Acesso em: 28 ago. 2020 .

VIEIRA, Marcelo de Mello. Direito de crianças e de adolescentes à convivência familiar. 2. Ed. Belo Horizonte: D’Plácido, 2019.

VIEIRA, Marcelo de Mello; SILLMANN, Marina Carneiro Matos. Adoção à brasileira à luz da doutrina da proteção integral da criança e do adolescente. In: Direito de crianças e de adolescentes: Crimes contra a criança e o adolescente - um olhar sobre a relação entre o Direito Penal e o Direito Infantojuvenil. Belo Horizonte: D’Plácido, 2020, p. 61-94.

\section{DADOS DA PUBLICAÇÃO}

Categoria: artigo submetido ao double-blind review.

Recebido em: 21/09/2020.

Aceito em: 11/08/2021. 